\title{
Science meets Practice - Practice meets Science: Intervention Research as "Method" for Citizen Science?
}

\section{ao. Univ.-Prof. Mag. Dr. Paul-Horn, Ina}

Alpen-Adria-Universität Klagenfurt

Universitätsstraße 65-67, 9020 Klagenfurt, Austria

Institute of Instructional and School Development

Sterneckstraße 15, 9020 Klagenfurt

ina.paul-horn@aau.at

Citizen Science reconfigures the classic division of labour between citizens and science. A specific organization of the research project therefore is required. Prerequisites for such a research are described in the article. 


\section{Introduction}

Citizen Science reconfigures the classic division of labour between citzen and science. Citizens have knowledge in their fields of practice, and specialisation has produced several fields of experts. How does one bring together this distributed knowledge in relation to a particular problem? Science acts as an educational and learning process in that it gives people a better understanding of themselves, and contributes to the development and democratisation of society (cf. Heintel/Lerchster 2019: 42ff.). Indeed this interrelation between 'scholars' and society was already described by J.G. Fichte as a 'mutual give and take' (cf. Fichte 1794/1966: 32, trans. IPH). My aim in this paper is to show how intervention research can be a "method" for organising this interrelation between science and practice and practice and science in a new way. Method does not only mean a special set of methods, but an attitude towards the other persons and therefore an awareness of the preconditions which must be given or organised in doing this kind of research successfully.

\section{What is Intervention Research?}

Intervention research like Citizen Science is paradigmatically related to similar practice-oriented research approaches that go back to the work of Kurt Lewin (cf. Lewin 1948/1968; Paul-Horn \& Rabl 2021) and involves those "researched" for the purpose of a joint research and learning process. Although certain differences in roles and tasks remain, the otherwise common separation of (research) subject and (researched) object is eliminated via a specific research design and an "architecture of participation" (Lerchster \& Heintel 2019: 48, trans. IPH). The goal is to lift the existing explicit and implicit knowledge from the respective research field, to work out its significance in a joint self-enlightenment process, to connect it with theories and to collaboratively develop potential solutions.

At the Faculty of Interdisciplinary Research and Continuing Education (IFF) of the University of Klagenfurt, the "Doctoral Programme in Intervention Research (DKI)" was established in 2009 by an interdisciplinary team of philosophers, group dynamics specialists, psychologists and others. It was aimed at persons from different disciplines who had access to social fields through their own professional practice, whose research interests were interdisciplinary, and who wanted to deal with concrete problems in a research process. The programme also encouraged graduate students to conduct their research in an epistemological manner. In its 13-year existence, the programme resulted in a considerable number of dissertations (cf. Paul-Horn \& Rabl, 2021). And through its "'conjunctive experiential space'" (cf. Mannheim 1922/1980, trans. IPH), an 'intervention-researching community' emerged and became established.

The Interdisciplinary Doctoral Programme was designed along three focal points:

1. Philosophy of science and reflection of science, including philosophy of the science of intervention research, where intervention research means research to generate knowledge in cooperation with those affected ("the practice"), i.e., to transform "affected persons into participants".

2. Methodological skills such as the development of a research design that is open to changes emerging from the field. Conducting and evaluating qualitative in-depth interviews, participant observation, psychoanalytically oriented organisational observation (cf. Paul-Horn 2006) as well as organising feedback of interim results to respective research partners. This feedback is constitutive for intervention research.

3. Recognising and managing open-ended processes in groups and organisations through experiential learning in their own learning arrangements. The study of group dynamics as a university discipline has established itself in the German-speaking world primarily at the University of Klagenfurt. The "Training Group" (standing in the tradition of Kurt Lewin) and the "Organization Laboratory", a unique Klagenfurt development, are experience-based learning formats. Both are approximately 6-day-long events, which in principle, have an experimental character and focus on groups or organisations as social formations. The learning settings allow the acting individuals and subgroups to become the subject of their own interactions, concerns, and emotions, supported by trainers. The participants are thus both subject and object of a process of self-exploration (cf. Krainz 2005: 313). 


\section{Conditions for Participatory and Inter- and Transdisciplinary Research}

Intervention research as participatory and inter- and transdisciplinary social research sees itself as research into existing social systems. It is guided by the idea of freedom of the persons and groups involved. This fundamental recognition of the autonomy of counterparts (individuals, collectives - or in intervention research 'research partners') requires a specific organisation of the research project. Attention is paid to the careful planning of processes, which in turn requires a certain attitude and special skills of the researchers involved.

The following should be noted as prerequisites for successful research:

- There is a need for an adequate organisation of dialogical communication processes - both between scientists as well as between science and 'practice', i.e., the research partners.

- The space: Which stakeholders need to be given which space, which presence; where will the surveys be conducted; how will researchers and research partners be placed in the space; how many are needed to work well in subgroups; when to work bilaterally, when with focus groups, and so on.

- Time: How much time is allowed for getting to know each other, for finding a common language (interdisciplinary among scientists, but also between science and practice); understanding different 'system logics' requires time; the duration of in-depth interviews needs to be clarified, as well as how much time is needed between interviews and for feedback.

- In intervention research, processes and forms of organisation are constitutive of content and are thus the object of reflection. Thus, it is the task of the organisation of the research process to enable freedom.

- Participant autonomy also requires a recognition process (cf. Lerchster \& Heintel, 2019: 53). Research partners bring their everyday experiences with them, which should be taken seriously. No position is excluded from the outset, devalued or understood as incorrect. This individual recognition is followed by a mutual understanding with increasing awareness of all conditions, which in turn sets a collective recognition process in motion and subsequently not only enables but also accelerates the generation of joint results.

- Each step in the research process produces effects. These effects must both be perceived and be reacted to accordingly, i.e. the phenomena and emotions that occur must be reflected upon with the participants (cf. Paul-Horn \& Turner, 2016: 265ff.).

- Different everyday experiences come together in participatory processes. These can also lead to conflicts. For scientists, knowledge about contradictions inherent in the system, which can be the cause of conflicts, is necessary (cf. Heintel 2005), as is the handling of conflictual situations.

- Intervention research is usually teamwork. Therefore, it proves advantageous when in the context of intervention research projects, additional group and organizational dynamic competencies are acquired (cf. Paul-Horn 2018).

\section{Relevance for Citizen Science}

Citizen Science not only includes but depends on the knowledge of citizens. Sometimes citizens only collect data, and scientists are left to evaluate, interpret and think about the consequences. When citizens participate in the early stages of defining the problem or are involved in the entire research process, intervention research clearly overlaps with Citizen Science. In this case, the additional competencies of intervention research scientists could certainly also be applied to and be helpful in Citizen Science projects. These competencies include, in particular, the knowledge of how groups function, how they can be managed, and what it takes to be effective. They can be learned in experience-based, groupdynamic learning formats, such as those developed at the University of Klagenfurt. 


\section{References}

[1] J. G. Fichte, Einige Vorlesungen über die Bestimmung des Gelehrten, in Gesamtausgabe Werke Band 3. Werke 1794 - 1796 of J. G. Fichte, Friedrich Fromann Verlag, Stuttgart-Bad Cannstatt 1794/1966, 22-68.

[2] P. Heintel, Widerspruchsfelder, Systemlogiken und Gruppendialektiken als Ursprung notwendiger Konflikte, in Handbuch Mediation und Konfliktmanagement of G. Falk, P. Heintel, E. E. Krainz, Verlag für Sozialwissenschaften, Wiesbaden 2005, 15-33.

[3] E. E. Krainz, Erfahrungslernen in Laboratoriumssettings: Trainingsgruppe und Organisationslaboratorium, in Handbuch Mediation und Konfliktmanagement of G. Falk, P. Heintel, E. E. Krainz, Verlag für Sozialwissenschaften, Wiesbaden 2005, 311-326.

[4] R. E. Lerchster, P. Heintel, Interventionsforschung in ihrer Beziehung zur Transzendentalphilosophie, in Interventionsforschung Band 3: Wege der Vermittlung. Intervention Partizipation of M. Ukowitz, R. Hübner, Springer, Wiesbaden 2019, 27-58.

[5] K. Mannheim, Eine soziologische Theorie der Kultur und ihrer Erkennbarkeit (Konjunktives und kommunikatives Denken), in Karl Mannheim. Strukturen des Denkens of D. Kettler, V. Meja, N. Stehr, Suhrkamp, Frankfurt 1980, 15-303.

[6] I. Paul-Horn, Zukunft der Praxis - Zukunft der Wissenschaft. Forschungsbericht über 12 Jahre interdisziplinäres DoktorandInnenkolleg Interventionsforschung (DKI). Manuskript, Klagenfurt 2018.

[7] I. Paul-Horn, A. Turner, Emotionen für die Forschung wahrnehmen lernen. Work Discussioneine Anwendung der psychoanalytisch-orientierten Beobachtung im Interdisziplinären DoktorandInnenkolleg Interventionsforschung, in Interventionsforschung, Band 2: Anliegen, Potentiale und Grenzen transdisziplinärer Wissenschaft of $R$. E. Lerchster, L. Krainer, Springer, Wiesbaden 2016, 261-285.

[8] I. Paul-Horn, Psychoanalytisch orientierte Organisationsbeobachtung. Erfahrungen mit einer Methode, in Klagenfurter Beiträge zur Interventionsforschung. Band 4. Klagenfurt 2006 [http://netlibrary.aau.at/obvuklkbif].

[9] I. Paul-Horn, T. Rabl, Forschung, die eingreift: Beiträge zur Theorie und Methodik der Beratung, Springer, Wiesbaden 2021.

[10] I. Paul-Horn, T. Rabl, Interventionsforschung: Die Überwindung des Praxisproblems in der Wissenschaft, in Forschung, die eingreift: Beiträge zur Theorie und Methodik der Beratung of I. Paul-Horn, T. Rabl, Springer, Wiesbaden 2021. 